\title{
Early childhood education in the outdoors in Aotearoa New Zealand
}

\author{
Sophie Alcock ${ }^{1} \cdot J_{e n n y}$ Ritchie $^{1}$
}

Published online: 15 February 2018

(C) Outdoor Education Australia 2018

\begin{abstract}
Early childhood care and education services in Aotearoa New Zealand drew initially on the Fröbelian model of the kindergarten or 'children's garden'. Later models such as the Kōhanga Reo movement, the highly respected curriculum Te Whāriki: He whāriki mātauranga mō ngā mokopuna o Aotearoa, and the Enviroschools programme are grounded in te ao Māori, Māori worldviews, that feature a strong connectedness to place, and a deep sense of a spiritual inter-relationship with the land, mountains, rivers, and oceans. This article considers how the imported Scandinavian/European/UK models of 'forest schools' might fit within this context. To illustrate early childhood education in the outdoors in Aotearoa (New Zealand) we draw upon research conducted in early childhood settings in this country that illuminates children's experience in the outdoors. We draw upon critical early childhood scholarship to theorise this situation of forest schools emerging in Aotearoa, along with influences from the forest school movement evident in existing New Zealand early childhood services. The article suggests that traditional Indigenous Māori worldviews and knowledges give meaning and contextualised authenticity to 'forest schools' approaches in early childhood education in Aotearoa (New Zealand).
\end{abstract}

Keywords Early childhood outdoor education · Forest schools · Aotearoa New Zealand

\section{Introduction}

It is interesting to observe the variations of 'forest school' and Reggio Emilia inspired early childhood programmes spreading rapidly in Aotearoa. Fundamental elements in

Sophie Alcock

sophie.alcock@vuw.ac.nz

$\triangle$ Jenny Ritchie

Jenny.Ritchie@vuw.ac.nz

1 Victoria University of Wellington, Wellington, New Zealand 
both Reggio Emilia inspired and 'forest school' programmes have been imported from other cultures and countries and superimposed or added to existing curriculum. These programmes contain and represent some wonderfully inspiring and very useful pedagogical elements, however in the current rather depressed early childhood context in Aotearoa they feel a little cargo cult-like (Johnson 2000), as if by being attractive overseas imports they might revive early childhood care and education in Aotearoa, or at least provide a competitive edge in a profit-oriented privatised sector.

We suggest that within the diverse range of early childhood care and education provision and programmes, we have much in Aotearoa-New Zealand that may have been overlooked in the rush to emulate these international programmes. The rapid growth in number of early childhood care and education services has paralleled the government's push for increasing child participation in these settings, alongside shifts in societal expectations and the economic imperatives of both parents continuing in the workforce, whilst even very young babies are cared for on a full-time basis by a largely privatised sector. Such is the neo-liberal way. The ideals of 'forest schools' can provide an appealing alternative, particularly for urban families with sustainability concerns, to the narrowing more academic and stultifying outcomes-based programmes focussing on school readiness.

This article draws on the experience and research of two scholars of early childhood care and education to problematize the introduction of 'forest school' ${ }^{\text {approaches into }}$ early childhood education settings in Aotearoa. In order to provide context for this recent development, we consider the strong environmental ethos evident in wider New Zealand culture, and describe in particular, the Enviroschools movement. We then outline some key Māori conceptualisations in relation to young children and the outdoors, beginning with Māori cosmology. We draw on the thesis material of Makereti, published in 1938, in which she described the traditional childrearing beliefs and practices of her Te Arawa tribe (Makereti [Maggie Papakura] 1938). Recent New Zealand research focussing on early childhood education is canvassed, offering insight into how the introduction of 'forest school' ideas must navigate a rich cultural heritage in Aotearoa that differs from that in northern Europe and the UK.

\section{Environmental education/activism in Aotearoa New Zealand}

New Zealand proudly claims and promotes internationally an image of being a 'clean green', 'pure' country, although this is steadily becoming problematic as the result of the pollution of lands and waterways caused by drastic intensification of the dairying industry in recent decades (Joy 2015). The New Zealand economy is literally grounded in the outdoors, through its reliance on agriculture and tourism. The outdoors may be considered a core part of New Zealanders' identities, with 'outdoorsy' and 'caring about the environment' being two of the top ten attributes voted by New Zealanders as contributing to conceptions of national identity (Wade 2016).

Respect and concern for the outdoors or natural world can be seen in the activism of groups such as Forest and Bird (Forest and Bird Society n.d.), the New Zealand

\footnotetext{
${ }^{1}$ We use speech marks to indicate that we are using the term 'forest schools' in a generic sense, and are not referring to any specific model, such as that of the UK Forest Schools - which we address using capital letters.
} 
Association for Environmental Education (New Zealand Association for Environmental Education 2017) and the Enviroschools movement (Enviroschools n.d.). Enviroschools is a sustainability-focussed programme integrating Māori worldviews. The initiative began in Hamilton, New Zealand in 1993, with three schools, and now includes around 1000 schools and 200 early childhood centres (Toimata Foundation 2015). The Enviroschools website expresses their philosophy]

The Enviroschools kaupapa [philosophy/purpose] is creating a healthy, peaceful and sustainable world through facilitating action-learning; where intergenerations of people work with and learn from nature. It weaves in Māori perspectives, combining traditional wisdoms with new understandings. Importantly, our kaupapa reminds us to be in connection: to love, care for and respect ourselves, each other and our planet. (Enviroschools n.d.)

The Enviroschools model thus contains an integral focus on Māori perspectives. Children attending Enviroschools early childhood services are engaged in a wide range of activities such as biodiversity enhancement, waste minimisation, food production and use, water conservation to name a few.

Kōhanga reo, Te Whāriki and Enviroschools are all home-grown, 'flax-roots' educational models that are keenly committed to reflecting te ao Māori (a Māori worldview), an integral feature of which is a deep respect for the environment, although the nature and extent of how this is enacted varies widely across different early childhood settings.

\section{Māori worldviews and early childhood outdoor education in Aotearoa New Zealand}

Māori cosmology upholds a genealogical connection between the original parents Papatūānuku (the Earth Mother), Ranginui (the Sky Father), and their offspring the Atua/ Gods of the forests, seas, winds, and cultivated as well as uncultivated foods. The forests, forest creatures, and humans are all descendants from Tane Māhuta, the Atua/ God of the forests. A deep sense of spiritual interconnectedness pervades te ao Māori (the Māori world).

Traditionally, Māori children learnt an Indigenous ecological literacy based in generations of wisdom gleaned from the forests, seas, stars and soils (Makereti [Maggie Papakura] 1938; Pere 1982/1994; Royal 2007). Makereti, a member of the Te Arawa tribe of the Rotorua geothermal region, describes how in the era of 'The Old-Time Māori', children were often taught by their Elders, who were the repositories of tribal knowledges. They learnt "the names of the birds of the forest, and of the different trees and shrubs and plants, all the names of which the old people knew, and wonderful stories of the mountains, rivers, and streams, as though they were living human beings" (Makereti [Maggie Papakura] 1938, p. 151-152). Children were encouraged and trusted to explore their environs:

A child is free to play when and where he likes, and always has companions .... It is extraordinary how a Māori child knows the danger of fire or boiling water. 
Although he is free to wander where he likes, and even plays with fire and goes among the boiling pools, you will scarcely hear of a child being burnt or scalded. The children were fond of takaro (play). They had few toys, yet they amused themselves making mud pies, playing hunahuna (hide and seek... and many other games). (Makereti [Maggie Papakura] 1938, p. 137).

These aspects of intergenerational knowledge transmission and respect for the natural world were foundational to the later creation of the kōhanga reo movement, which focuses on early childhood education, language revitalisation and whānau (family) development. The kōhanga reo movement began in 1982 as a response to research that had indicated that there were few speakers of Māori left, and that the remaining fluent speakers were Elders (Benton 1997). From the start it was a Māori-led initiative with its primary focus the revitalisation of the Māori language, along with the promotion of Māori worldviews and traditional ways of being, knowing and doing (New Zealand Ministry of Education 2009). Many kōhanga reo are tribally and rurally located, and there is strong recognition of local landmarks such as forests, rivers and mountains threaded throughout the programmes, with the spiritual and physical, tangible and intangible aspects seen as integral (Education Review Office 2006).

The first early childhood curriculum for Aotearoa (New Zealand), Te Whariki: He whāriki mātauranga mō ngā mokopuna o Aotearoa (New Zealand Ministry of Education 1996), drew on the richness of te ao Māori (the Māori world). The document included as 'Part B' an integral Māori language text that expressed aspirations for early childhood care and education programmes with respect to Māori children. This Māori text was infused with a deep respect for Papatūānuku, the Earth Mother, expressing the intention that children will learn about their ancestral histories in relation to their whenua (land). It also articulated the expectation that children will live in close spiritual connection with their whenua, will learn its stories and will know how to care for it (New Zealand Ministry of Education 1996). ${ }^{2}$ Beyond the Māori text the document made it clear that early childhood services needed to develop relationships with local tangata whenua (Indigenous people, i.e., Māori) and that respect for Papatūānuku "should be promoted" (p. 54).

In the decades before Te Whāriki (1996), early childhood care and education (ECCE) programmes worked within European traditions that valued children playing outdoors, though within the confines of the ECCE service fences and gates (May 2013). ECCE in Aotearoa inherited theory and ideals inspired by both Fröbel and Rousseau that valued opportunities to support children developing 'naturally', like plants growing in gardens. The progressive ideals of the New Education movement that began in Europe with Freudian theory further emphasised children playing outdoors and an appreciation of children's messy play (May 2013). In the 1930's Susan Isaacs visited New Zealand as part of a contingent spreading the New Education Fellowship's ideas around the western world (Campbell 1938). Large outdoor sandpits and space to run and climb became hallmarks of community based ECCE services in

\footnotetext{
${ }^{2}$ Prior to this article being published, a new version of the curriculum was released by the New Zealand Ministry of Education, which is known as Te Whāriki 2017. The Māori section has been shifted to be separated from the rest of the document and is now known as 'Te Whāriki a te Kōhanga Reo' (The Whāriki for the Kōhanga Reo).
} 
the period from the 1930s until the turn of this century, with ECCE services sometimes resembling very large backyard gardens (Stephenson 1999). However, due to the dominant hegemony of the colonising culture, Māori perspectives, including their views of inter-relationship with nature, were largely excluded from these settler models of ECCE. Māori perspectives have increasingly been acknowledged since the introduction of the first New Zealand early childhood curriculum, Te Whariki, in 1996. This was an explicitly 'bicultural' document requiring attention to Māori language and culture alongside that of the dominant western culture (New Zealand Ministry of Education 1996).

Interestingly, this historical alignment between European and Māori traditions has recently been refreshed, building on the growing popularity of Forest School in the UK (see Leather 2018), a development drawing on similar initiatives originating across northern Europe, primarily in the Scandinavian countries, where being outdoors all year round is part of the cultural heritage (Sandsetter 2014). The oft-repeated saying: "there is no such thing as bad weather, only poor clothes," rhymes when spoken in the original Swedish, Danish and Norwegian languages. It encapsulates the spirit of friluftsliv that is expressed in early childhood education in the creation of opportunities for young children to enjoy learning and playing freely, in the outside air, despite, or possibly because of, the very cold northern winters (Sandseter and Lysklett 2017). Skovbørnehave (forest kindergartens) in Denmark are one such initiative (Sandseter and Lysklett 2017). Young children attending such early childhood settings in Scandinavia are likely to be taught cultural skills such as whittling with sharp knives. They may learn to identify animal tracks and experience cooking on open fires, as well as enjoying the freedom of climbing trees, building shelters from fallen branches, and just playing. Simply being outdoors and in nature is seen as desirable and healthy, exemplifying the Scandinavian cultural concept of friluftslif (Sandseter and Lysklett 2017).

Similarly, in Aotearoa, a basic characteristic of early childhood outdoor education involves children and teachers regularly and repeatedly visiting a forest-bush-park-farm outdoors space. This place becomes the school (or early childhood setting) beyond the usual gates, fences and walls that constrain play-spaces. This area can sometimes contain a small shed, where children can leave bags and other gear, but these arrangements vary.

In Aotearoa variations of these outdoor-based programmes are sometimes referred to as 'bush kindy' [vernacular for kindergarten], or simply bush, park, or farm days, as well as 'forest kindy'. Like the European forest kindergartens these programmes are also run on a regular basis, outside the physical grounds of the early childhood centre. Children repeatedly go to the same outdoor setting, beyond the centre's fence, in order to participate in these forest kindy types of programme.

However, unlike the Scandinavian forest kindergartens, the New Zealand versions are not full-time outdoor programmes. Instead, time spent in the outdoor place involves children, teachers and often some parents, visiting their forest, bush, park or farm place for a specified time that can be anything between a half or full day, weekly, fortnightly or monthly, and not necessarily all year round. The emphasis seems to be on allowing children to simply be present in the natural world of the bush, park, farm or forest. We are not aware of teachers in these outdoor focused programmes making many pedagogical connections with the historical, cultural and spiritual meanings that forests may carry. 
In Aotearoa, research regarding early childhood education in the outdoors is limited, although three studies do address relatively recent initiatives. The first of these is focused on integrating te ao Māori perspectives within a sustainability kaupapa (philosophy) of "caring for ourselves, others and the environment" (Ritchie et al. 2010, p.66). Each of the ten early childhood services from around the country involved in this project incorporated engagement in the outdoors. However, this did not necessarily mean venturing beyond the early childhood setting's fences every day, and the frequency of such excursions varied.

One child-care centre in an urban setting made regular trips to a nearby stream, monitoring the condition of its water and supporting a local community project to replant its banks with indigenous shrubs. Other centres participated in regular beach and park clean-ups, and one engaged with a local marae in tree-planting. At all the centres children were actively engaged in gardening, composting, preparing and eating produce from their gardens, and sharing this produce more widely in the community. Whilst many of these activities were guided by teachers, children often came to take a leading role and were confident in articulating their understandings of the importance of caring for Papatūānuku and Ranginui. Yet many of the defining characteristics of 'forest schools' were not aspirations of these centres nor were they visible. And as one of the project co-directors, I (Jenny) don't recall the subject of 'forest schools' arising during the two year period of data collection and analysis, from 2008 to 2010.

The second study investigates the Ngahere Project (Kelly and White 2012; Kelly et al. 2013), the initial provocation for which came from teachers who had been on study tours to Europe and the United Kingdom focussing on Forest Schools. Some teachers within the study were critical of importing international trends in early childhood education directly into the Aotearoa context. The final report for this project points out that "many of the key elements that define 'forest schools' were already evident in early childhood services in Aotearoa, prior to the recent interest in importing and applying aspects from Forest Schools (Kelly et al. 2013, p. 6).

One of the six early childhood services included in the Ngahere Project, Maungaarangi Kindergarten and Whanau Centre, chose to focus on Māori knowledges, posing the research question: What can local tikanga Māori [Māori traditions] teach a kindergarten learning community about engaging with nature? Experiences of nature for children attending this kindergarten were mainly within the confines of their large outdoor area rather than beyond the fence bounding the centre. The findings from this kindergarten's contribution to the project are summarised in the final report, where it is recorded that "teachers realised the depth of the children's understanding of the kindergarten's kaupapa [philosophy] and tikanga Māori. Elders identified that the kindergarten curriculum - even within the gates - was reinforcing tikanga drawn from local and wider Māori ways of knowing” (Kelly et al. 2013, p. 5).

The pedagogical approach at Maungaarangi kindergarten emphasises humans engaging with nature through the frequent re-telling of pūrākau (Māori traditional stories). In one particular story, a man called Rata neglected to ask permission from Tāne, the spiritual guardian of the ngahere (bush), to chop down a tree with which to build a waka (canoe) and thus was thwarted in progressing this activity by the creatures of the ngahere. According to the teachers, this fable demonstrated to children "an understanding of the natural world, making connections to the community and world, kaitiakitanga [guardianship], a sense of connection to the land, responsibility, asking 
for permission and following procedures" (Kelly et al. 2013, p. 38). Interestingly, this centre does not appear to have been directly influenced by international 'forest school' models, though the local kindergarten association to which this kindergarten belongs has for many years had a strong commitment to sustainability and to supporting its kindergartens to be part of the Enviroschools programme.

The third study was the only one we could find which directly described a version of forest school being applied in New Zealand, in this case in a rural public kindergarten (Braithwaite 2014). Braithwaite describes how as an extension of the kindergarten's sustainability focus, ten children plus teachers from the kindergarten make a weekly, heavily laden trek to a nearby bush reserve. There appears to have been (at the point that the article was written) little engagement if any with local Māori, although children demonstrated that they knew some of the Māori names for the birds they encountered. This is despite the expectations within Te Whäriki that teachers liaise with "local tangata whenua" (Indigenous people) and promote respect for Papatūānuku (Earth Mother)(New Zealand Ministry of Education 1996, p. 54).

Pacini-Ketchabaw (2013) has raised concerns about the dislocatedness of forest school approaches which, in providing children and their families with a sense of 'connecting with nature', are simultaneously ignoring the histories of colonial dispossession of Indigenous people and thus of their intimate knowledges and connection with their lands and forests. She asks us to consider "what might happen when we pay attention to how Indigenous peoples and their ontologies and epistemologies are erased from child care forest pedagogies, from local ecologies, and from discussions of children in nature?" (p. 356). This is an important consideration for teachers in Aotearoa, given our commitment to Māori and the expression of this as a pedagogical expectation within our curriculum.

\section{Tākaro (play) in early childhood outdoor education}

It seems that there is a trend emerging in Aotearoa for these outdoor initiatives in early childhood education to be labelled as forest kindergarten or something similar, drawing on developments in the UK especially. Anecdotally we hear of increasing numbers of childhood education and care centres embracing various versions of forest kindergartens in their programmes. The personal communication from a parent presented below speaks to what we believe are fairly common sentiments concerning these initiatives.

At my daughter's early childhood centre her favourite day each week is forest kindy day. She waits all week for forest kindy day when the kids, some teachers and parents go to the town belt park for half a day. The children play in the bush and climb trees. A few parents don't allow their children to join in. Those parents want their children to stay inside the centre and learn. I feel sorry for those children who stay in the centre. (Parent, personal communication, $\left(9^{\text {th }}\right.$ May, 2017)

This story encapsulates the popularity of forest kindergarten approaches and hints at an acknowledged tension around perceptions of play and learning. Learning is perceived by some as occurring only inside the early childhood centre, while free play happens outside and away from the centre. We are familiar with the particular setting which the 
anecdote above refers to. It has a small semi-outdoor space with concrete underfoot which is half covered by a roof, so is always shaded, with no sun and restricted views of the sky. Children do play there, however that space provides a stark contrast with the wild park that they visit on forest kindy days. Children's play in this centre outdoor space is likely to include more direct teacher involvement than it may in centres with larger outdoor areas, offering another contrast. Early childhood teachers in Aotearoa are commonly rostered for outside duty, so children are not alone when outdoors. Furthermore, early childhood teachers are taught to interact directly with children since part of their role as teachers is understood to be that of teaching children to learn, irrespective of whether indoors or outdoors. However early childhood teachers generally seem to allow children more freedom with less teacher control and interaction when outdoors (Stephenson 1999).

Allowing children the freedom to be and to play in and with nature stands out as a feature of Forest School where children are generally expected to simply learn through playing freely, in and with the natural outdoor environment (Knight 2009). This simplistic view of play and of nature harks back to that traditional romantic early childhood mantra: children learn through play. The complexities of play, culture, nature and learning are overlooked when play is understood narrowly as simply being about how children learn, with nature providing a passive learning context.

In his critique of Forest School in the UK, Leather (2018) points out that the pedagogical underpinnings of forest schools, particularly notions of play, are currently under-theorised, and we suggest that this criticism is also valid in Aotearoa. Play is always cultural, however socio-cultural theories of play have tended to prioritise pretend play within narrow understandings, whereby children recreate their culture through re-enacting adults' practices in 'as-if' play (Elkonin, 1999; Vygotsky 1978).

The dynamics of the natural world as both the context and partner in play add lively layers to the matrix of play by emphasising the interactive, interpenetrating, and interconnected dimensions of play as process. These dimensions are included in the Māori worldview of tākaro (play). Tākaro includes ecological and cosmic understandings of play as an interconnecting phenomenon: the world is an arena where Gods, birds and humans play and interact together with/in nature. For example the mythic demi-God Maui challenges Te Rā the sun, drawing upon spiritual incantations and the strength of ropes woven from harakeke (flax), in order to slow the progress of Te Rā across the sky and thus extend the amount of daylight. A further example is seen in the following 'School News' item from 2011 about tākaro which describes the views of the late Māori scholar, Dr. Hirini Melbourne, on playing the game of Rahi.

Birds (manu) would be called down with flute playing to consecrate the ancient fields of play, so that all involved with the ball games could receive their blessing. Hence the proverb, "E ko nei i te wao nui tapu o Ra-hi" (proclaiming the sanctuary of Ra-hi). Ra-hi also means 'to haul up the sun' - a prosaic description of ball throwing. ... Just as forests, the realm of Tane Mahuta, are blessed daily with the raucous cacophony of birds, so was their 'attendance' vital to the sustenance of ancient game playing competitions. The birds could also be seen as family guests, connected by whakapapa (genealogy) - with Tane being the father to birds and mankind. (Melbourne, as cited in Te Reo Resources: He Taonga Takaro 2011). 
In this context, play includes all-encompassing, active and situated processes that are better understood as active verbs than as passive nouns (Alcock 2013). Playfulness, too, is an active attitude epitomised by the trickster, Maui, who communicates with and even shape-shifts to be as one with his friends the birds.

As Māori understandings of tākaro emphasise, play and playfulness are processes that come alive in the living worlds of nature: forest, bush, parks, with sun, rain, water, wind and sky. For the purposes of this article the forest, the bush, the park, provide the physical location, the playing field, that provokes children to play. This field is more than context; it is also the invisible, emotional and spiritual, sensed and felt, dimensions of playing as an activity (Alcock 2017).

The playing field, be it forest, bush or park, is a physical place and the activity of playing there provokes feelings: felt but invisible third spaces that emerge inbetween and amongst players and place. This in-between space of play is neither inside the self nor outside, but is a space of feeling. Winnicott (1974) referred to this emergent felt play space as potential or transitional space. The act of playing can open players up to the in-between felt spaces that emerge and shift and change between and amongst children playing in and with nature, like Maui, playfully creating nature with the help of the Gods. Culture, spirituality, emotion, art and play all emerge and are recreated in this felt in-between space. Playing freely in wild places (forest-bush-park) can support children to relax, to feel and to open up to the intra-active creativity of potential spaces, by being and becoming actively alive and open to their sensoriality and connectedness within the worlds of nature (Winnicott 1974).

From these broadly inclusive perspectives, play is far more than pedagogical understandings of learning can encompass. Playing is more than pedagogy because it includes creative, spiritual and emotional as well as cognitive dimensions of being. The challenge that arises for early childhood education is to enquire as to whether our understandings of pedagogy can be extended to include children's creative, emotional and spiritual wellbeing and sense of inter-connectedness and inter-relationality within their worlds, both indoors and out (Ritchie 2013).

\section{Conclusion}

I (author Sophie) recently heard an early childhood teacher explain to a group of international visitors how, inspired by the forest kindergarten movement, children at her centre now regularly visited the nearby bush-public gardens on a regular basis. When I mentioned this to a colleague who had been the manager of that same centre thirty years previously, she incredulously recalled how they too had visited those gardens on a regular basis. The older children had carried little backpacks with food, drink and extra clothing and often stayed and played in these same bush-gardens all day, while the younger children in pushchairs returned to the centre for lunch and to sleep. This shift in practice from regularly visiting the bush, to staying inside the boundaries of the centre, to again visiting and being in the bush, occurred over a thirty five year time period during which early childhood care and education services grew in number, the sector became more 'professional' and regulations became tighter. In this regulated and risk- 
averse era, the 'forest school' movement possibly provides some legitimacy for early childhood care and education programmes venturing beyond the service gates and allowing children to play freely in wild places.

Researching and writing this paper has provoked us to reflect on the rich outdoor heritage of early childhood care and education programmes in Aotearoa. It has also increased our awareness of how current market-driven imperatives are deprioritising opportunities for children's outdoor, wild and free, play and learning.

As stated earlier, the early childhood care and education sector may be largely overlooking the pedagogically under-theorised potentials of existing programmes. Enviroschools incorporate aspects of the rich kaupapa of Maori worldviews of nature while also emphasising sustainability. All early childhood programmes in Aotearoa are obliged, under the obligations of the 1840 Tiriti o Waitangi | Treaty of Waitangi, to include Māori perspectives in their programmes to some extent although how this is done varies. However, Māori theories of nature and our place in the world offer a wonderful opening for deepening our understandings of children, play, social, emotional and spiritual learning, and sustainability in and with the natural world. Such understandings emphasise relatedness and interconnectedness, as well as sustainability. Children playing, learning, being and becoming themselves in relation to and with the world, including worlds of nature, are complexly interconnected processes.

Questions that arose for us in the writing of this paper included reflecting on how we might philosophise and theorise in many ways about children's experiences in the outdoors, yet we cannot respond with any sense of certainty. Aware that our values lie with nature and sustainability we wondered about overromanticising nature, natural worlds and wild places and if such romanticism really is an issue, in the face of 'big' environmental issues like climate change. We became increasingly aware of how, for example, teachers travelling to the UK to study Forest School pedagogy might return to perpetuate colonial legacies that can naively romanticise ideals around beauty in nature and wild places. In this era of increasing threats of climate change disturbances, there is clearly a danger in positioning humans as outsiders observing nature, rather than applying Indigenous Māori worldviews of humans inter and intra-actively living, playing, knowing, and relating within forest and other wild spaces.

Our newly revised early childhood curriculum, Te Whāriki (New Zealand Ministry of Education 2017), offers some optimism by specifying traditional Māori worldviews and understandings of the environment to be integral to meaningful curriculum, expressed in statements such as this: "Kaiako [teachers] support mokopuna [children] to engage respectfully with and to have aroha [love and respect] for Papatūānuku [Earth Mother]. They encourage an understanding of kaitiakitanga [environmental guardianship] and the responsibilities of being a kaitiaki [guardian] by, for example, caring for rivers, native forest and birds" (New Zealand Ministry of Education 2017, p. 32). Kaitiakitanga (environmental guardianship) thus becomes a responsibility for everyone in early childhood care and education in Aotearoa, and these services are to initiate the learning of dispositions that will empower young children to care for the environment for the rest of their lives. 


\section{References}

Alcock, S. (2013). Searching for play in early childhood care and education policy. New Zealand Journal of Educational Studies, 48(1), 19-33.

Alcock, S. J. (2017). Interpersonal fields of play. Early Child Development and Care, 187(5-6), 924-934. https://doi.org/10.1080/03004430.2016.1210134

Benton, R. (1997). The Māori language. Dying or reviving? Wellington: NZCER Retrieved from http://www. nzcer.org.nz/system/files/The_Māori_Language_dying_reviving.pdf

Braithwaite, D. (2014). 'One nearly landed on my finger': A forest kindergarten in rural New Zealand. New Zealand Journal of Teachers' Work, 11(1), 3-6 Retrieved from http://www.teacherswork.ac. nz/journal/volume11_issue11.php

Campbell, A. E. (Ed.). (1938). Modern trends in education: the proceedings of the new education fellowship conference held in July, 1937. Wellington: Whitcombe and Tombs.

Education Review Office. (2006). Evaluation indicators for education reviews in kōhanga reo. Wellington: Education Review Office.

Enviroschools. (n.d.). Enviroschools. Hamilton, New Zealand: About Enviroschools Retrieved from http://www.enviroschools.org.nz/about-enviroschools

Forest and Bird. (n.d.) Forest and bird. Retrieved from http://www.forestandbird.org.nz/.

Johnson, R. (2000). Colonialism and cargo cults in early childhood education: does Reggio Emilia really exist? Contemporary Issues in Early Childhood, 1(1), 61-78. https://doi.org/10.2304/ciec.2000.1.1.8

Joy, M. (2015). Polluted Inheritance New Zealand's freshwater crisis. Wellington: Bridget Williams Books.

Kelly, J., \& White, E. J. (2012). Pedagogy beyond the gate. The Ngahere project. Early Childhood Folio, 16(2), 5-11.

Kelly, J., White, E. J., Dekker, M., Donald, J., Hart, K., McKay, F., ... Wright, G. (2013). The ngahere project. Teaching and learning possibilities in nature settings. Hamilton, NZ. Wilf Malcolm Institute of Educational Research, University of Waikato. Retrieved from http://www.waikato.ac.nz/ data/assets/pdf_file/0007/146176/Ngahere-project_3-2013-03-14.pdf.

Knight, S. (2009). Forest schools and outdoor learning in the early years. London: Sage.

Leather, M. (2018). A critique of Forest School: Something lost in translation. Journal of Outdoor and Environmental Education (THIS ISSUE).

Makereti [Maggie Papakura]. (1938). The old-time Māori. London: Victor Gollancz Ltd..

May, H. (2013). The discovery of early childhood (2nd ed.). Wellington, N.Z.: NZCER Press.

New Zealand Association for Environmental Education. (2017). Retrieved from http://nzaee.org.nz/about-us/.

New Zealand Ministry of Education. (1996). Te Whāriki. He whāriki mātauranga mō ngā mokopuna o Aotearoa: Early childhood curriculum. Retrieved from Wellington:

New Zealand Ministry of Education. (2009). Te Whatu Pōkeka. Kaupapa Māori assessment for learning. Early childhood exemplars. Wellington: Learning Media.

Pacini-Ketchabaw, V. (2013). Frictions in forest pedagogies: common worlds in settler colonial spaces. Global Studies of Childhood, 3(4), 355-365.

Pere, R. R. (1982/1994). Ako. Concepts and learning in the Māori tradition. Hamilton: Department of Sociology, University of Waikato. Reprinted by Te Kohanga Reo National Trust Board.

Ritchie, J. (2013). Sustainability and children's inter-relationality with nature. In A. Grey \& B. Clark (Eds.), Ngā hurihanga ako kōhungahunga. Transformative teaching practices in early childhood education (pp. 107-116). Pearson: Auckland.

Ritchie, J., Duhn, I., Rau, C., \& Craw, J. (2010). Titiro Whakamuri, Hoki Whakamua. We are the future, the present and the past: caring for self, others and the environment in early years' teaching and learning. Final Report for the Teaching and Learning Research Initiative. Wellington: TLRI. Retrieved from http://www.tlri.org.nz/tlri-research/research-completed/ece-sector/titiro-whakamuri-hoki-whakamua-weare-future-present-and.

Royal, T. A. C. (2007). Te Waonui a Tāne - forest mythology. Part Three - Symbolism of trees and plants. Wellington: Te Ara Encyclopedia of New Zealand Retrieved from http:/www.teara.govt.nz/en/tewaonui-a-tane-forest-mythology/page-3

Sandsetter, E. (2014). Early years outdoor play in Scandinavia. In T. Maynard \& J. Waters (Eds.), Exploring outdoor play in the early years (pp. 114-126). Maidenhead, Berkshire: Open University Press.

Sandseter, E. B. H., \& Lysklett, O. B. (2017). Outdoor education in the Nordic region. In C. Ringsmose \& G. Kragh-Müller (Eds.), Nordic social pedagogical approach to early years (pp. 115-132). Cham: Springer International Publishing. 
Stephenson, A. M. (1999). Opening up the outdoors: a case study of young children's outdoor experiences in one childcare centre (Vol. no. 4). Wellington, N.Z: Institute for Early Childhood Studies, Victoria University of Wellington.

Te Reo Resources: Ngā Taonga Takaro. (2011). Retrieved from School News website: https://www. schoolnews.co.nz/2011/10/te-reo-resources-nga-taonga-takaro/.

Toimata Foundation. (2015). Enviroschools. Key findings from the nationwide census. Hamilton: Toimata Foundation Retrieved from http://www.enviroschools.org.nz/outcomes_and_benefits/2014evaluation/Enviroschools_census_WEB21.pdf

Vygotsky, L. S. (1978). Mind in society: The development of higher psychological processes. Cambridge: Harvard University Press.

Wade, A. (2016). What makes a Kiwi? That depends where you live. Retrieved from NZ Herals website: http://www.nzherald.co.nz/nz/news/article.cfm?c_id=1\&objectid=11585039.

Winnicott, D. W. (1974). Playing and reality. Harmondsworth, UK: Penguin.

Sophie Alcock is interested in children's emotional wellbeing from relational and socio-psycho-cultural perspectives that prioritise the systemic attachment contexts and the physical world within which children live, play and learn. She is also an early childhood teacher, which brings a pragmatic approach to her position researching and teaching as a senior lecturer in Education at Victoria university of Wellington, in AotearoaNew Zealand. Sophie particularly enjoys the complexities that emerge when observing and interpreting children playing indoors and outdoors.

Jenny Ritchie has been involved in the early childhood care and education sector since the 1970 s, as a childcare worker, kindergarten teacher, parent, teacher educator, education researcher, and more recently, a grandparent. She is an Associate Professor in Te Puna Akopai, the School of Education, at Te Whare Wānanga o te Ūpoko o te Ika a Māui, Victoria University of Wellington, New Zealand. Both her research and teaching focus on social, cultural, and ecological justice in early childhood care and education. 
Copyright of Journal of Outdoor \& Environmental Education is the property of Outdoor Council of Australia and its content may not be copied or emailed to multiple sites or posted to a listserv without the copyright holder's express written permission. However, users may print, download, or email articles for individual use. 